\title{
THE ISSUE OF PENALTIES AND ITS EXECUTION MODE: AN EMPIRICAL STUDY ON HUMAN RIGHTS EDUCATION
}

\author{
A. Guimarães, F. Rebelo \\ Universidade Portucalense (PORTUGAL)
}

\begin{abstract}
As Law teachers at Portucalense University, it has been our objective to research the position of our students with regard to human rights and, in particular, on criminal penalties, their forms of execution and security.
\end{abstract}

We previously conducted a first survey addressed to undergraduate students and, for this work, we conducted an identical survey on Brazilian students who attended the teaching part of the master's degree in Legal and Political Sciences specialization, at our University.

These students were presently in Portugal. We intend to understand their position on the theme based on their reality experienced in Brazil. The surveys were answered in the classroom, anonymously and freely. The students already have professional experience in the area of legal sciences, varying their ages between $30 / 40$ years.

The results of this empirical study showed respondents' sensitivity in human rights matters. Prevention, as an end to sentences, was unanimous. Almost everyone said they felt insecure in their country and most of them had also been victims of crime in their country. The majority of students are in favour of the resocialization of the prisoner imposed by the State. However, in relation to the remaining questions, the answers were diversified. This diversity is explained by motivations of a security nature given the extension of the criminal phenomenon in Brazil.

Keywords: Human rights education, prison sentences, purposes of the penalties, execution mode of penalties, insecureness, victims of crime.

\section{INTRODUCTION}

This is our second study on the perception of penalties, their forms of execution and the security of public life. Surveys were used. The answers were given by Master's students, of Brazilian nationality, who were in Portugal, at Portucalense University, attending the first part of this study cycle. The surveys contained eleven questions and the answers were given anonymously and freely in the classroom.

The theme boils down to the need to know whether the respondents consider that there is respect for human rights in the application of sentences, their modalities and their execution.

\section{METHODOLOGY}

We conducted a survey on Brazilian students who attended the teaching part of the master's degree in Legal and Political Sciences specialization, at our University. These students were presently in Portugal. We intend to understand their position on the theme based on their reality experienced in Brazil. The surveys were answered in the classroom, anonymously and freely. The students already have professional experience in the area of legal sciences, varying their ages between 30/40 years.

\subsection{The relevance of the study facing Brazilian penitentiary system's difficulties}

The criminal phenomenon and above all the Brazilian penitentiaries reality are different from the Portuguese. Despite the shortcomings of the Portuguese system, the Brazilian prison system is subject to severe criticism, a fact that the authors have noted in the various congresses in which they have participated, where they hear the expositions and reports of their counterparts, and in the literature to which they have had access. There are serious problems related to the lack of humanity in serving sentences, since the bankruptcy of the Brazilian prison system according to Greco [1], the overcrowding of prisons, which has negative consequences for the effectiveness of the principle of 
human dignity and the desirable resocialization of convicts. See Tamer [2], which, among other problems, calls attention to prisons overcrowding. The numbers are impressive. According to the National Survey of Penitentiary Information (INFOPEN), published in 2017, with data from June 2016, the prison population, distributed among the various prison establishments, was a total of 726.712 , for a capacity of 368.049 , representing a deficit of 358.663 vacancies and an average occupancy rate of $197,4 \%$ [3]. Now, added to the concerns of overcrowding, there is the problem of the precarious conditions of prison establishments in terms of hygiene and health conditions, Machado and Guimarães [4]. Prisons overcrowding is a serious and complex problem, that generates malaise, insecurity and dangers to all inmates, namely for health because it facilitates the spread of diseases to which it refers Souza [5].

\section{RESULTS}

\subsection{Questions}

1: Do you agree with life sentence?

R: 4 answers in favour, 8 against and 1 blank answer.

2 : Do you agree with death penalty?

R: 2 answers in favour and 11 against.

3: Do you agree with forced labour penalty?

R: 6 answers in favour and 7 against.

4: Do you agree with body punishment penalties?

$\mathrm{R}: 1$ answer in favour and 12 against.

5: Do you agree with the retributive end of sentences?

R: 6 answers in favour, 5 against and 2 blanks.

6: Do you agree with the preventive purposes of the sentences?

R: All in favour (13) - unanimity.

7: Do you agree with the correction/resocialization of the prisoner imposed by the State in the prison system, even against the convict's will?

R: 8 answers in favour and 5 against.

8: Do you consider that sentences should be more severe?

R: 9 answers in favour and 4 against.

9: The brazilian criminal justice system is:

a) very good: 0 answers;

b) good: 2 answers;

c) reasonable: 5 answers;

d) weak: 3 answers;

e) very weak: 3 answers.

10: Do you feel secure in your home country (Brazil)?

$\mathrm{R}: 1$ answer in favour and 12 against.

11: Have you been a victim of a crime in your home country?

$\mathrm{R}: 10$ answer in favour and 3 against.

\subsection{Discussion of the results. Explanatory of the data}

When it comes to the type of criminal sanction, there is no doubt that most respondents say they are against cruel and inhuman punishment. They are considered to be against life sentences, against the death penalty, against the penalty of forced labour and against corporal punishment. We found that 7 of the opponents of life imprisonment are simultaneously opponents of the death penalty. These responses reveal the respect due to the principle of human dignity. Really, for the legislative power, it cannot be worth everything, and it must shape its activity to the most basic constitutional principles, 
except for the list of criminal sanctions that depreciate and degrade the human being. These responses are of special value when the entire international community knows that Brazil has high rates of criminality and violent crime. According to Zaffaroni, "the contemporary rule of law is threatened by an unlimited growth of the punitive apparatus, especially of its executive and penitentiary agencies" [6]. However, the widespread spread of punitive and insurance trends in criminal law, the call for more penalties and more serious penalties ended up not being welcomed by our respondents.

The end of retribution for sentences was chosen by a majority, which leads us to a hardening of positions in the field of the ends of sentences. Soon after this position, surprisingly, the respondents ended up being favourable to the prevention purposes. We refer to Cesare Beccaria according to which "the purpose of penalties is not to torment and afflict a sensitive being, nor to annul an offense already committed", advocating an effect of penalties "more effective and more lasting on the spirits of men, and less torturous on the defendant's body" [7], without ever forgetting the principle of the personality of criminal law since, as Conde Monteiro states, "the legal and penal norms (...) are addressed to individual citizens and not groups or human masses" and "the legal and penal consequences are personal" [8].

Cross-analysing the responses, we find the following: 8 of the responses that are in favour of prevention purposes simultaneously defend resocialization as a state right and not as a prisoner's right. These 8 responses support that the State compels the prisoner to correct himself, to amend himself, in short, to force him and constrain resocialization. In this context, the prisoner's will would be dispensable and even indifferent. However, the convict's resocialization can only take place through his express will. Resocialization is only capable of producing its effects from the personal exercise of internalizing the "evil" practiced by the prisoner and in a totally voluntary way. Regeneration is personal and the choice of the prisoner. Resocialization is not achieved if the condemned person is unable or unwilling to understand the seriousness of his past behaviour and the consequences of those acts. Repentance will make you want to return to outer life responsibly. In short, the offender's correction is his right, which he may or may not exercise. On the other hand, there are prisoners who do not need re-socialization and others whose re-socialization is very difficult if not null. The position taken in the inquiries did not take into account the teachings of dogmatic criminal law. This may be due to the deep concern of the respondents about the high crime rates in their country, however, they were not aware of the inconsistency of the positions they adopted when they defended the imposed and forced correction of the prisoner.

We related the defence of the purpose of retribution of sentences with the answers to questions $1,2,3$ and 4: of the 6 answers that say yes to retribution, all answered no to the death penalty and corporal punishment, 3 of them answered no to the forced labour penalty and 4 of them answered no to life imprisonment. These responses are also somewhat surprising since there is a particular link between the sanctions' retributive purpose and this type of penalties.

We also related the defence of the purpose of retribution for sentences with the defence of more severe penalties: we found that there is greater coherence in these responses because among the 6 responses in favour of retributive purposes, 5 of them answered simultaneously yes to the most severe penalties (only 1 answered against).

Of the supporters of the existence of more severe penalties ( 8 in total), 5 answered no to life imprisonment, 7 answered no to the death penalty, 5 answered no to the penalty of forced labour and 7 answered no to corporal punishment. It follows that, despite defending the need to apply more severe penalties, this opinion does not influence the typology of the penalties, it should be understood that the proposed modification should only work at the quantitative level of the penalties and not at the qualitative level of the penalties, that is, it does not affect the type of sanctions but only its measure.

The feeling of insecurity in Brazil is dominant (12 out of 13 responses). The only respondent that said to felt safe in his country says he was already a victim of crime. There are also 3 responses that say they feel insecure in their country, but have never been victims of crime.

What is the relationship between respondents having been victims of crime (10 out of 13) and advocating the application of more severe penalties? 6 said yes to both questions, with 4 not establishing that link. We can conclude that there is no direct relationship between these two aspects. 


\subsection{Brazilian legal support}

The fundamental Brazilian law, that is, the Constitution of the Federative Republic of Brazil [9], in Title II, dedicated to fundamental rights and guarantees, in Chapter I which deals with individual and collective rights and duties, in Article 5, it provides that there will be no death penalty (except in the case of declared war), nor perpetual sentences, forced labour or cruel penalties. It further ensures that the sentences must be carried out in different prison establishments according to the nature of the crime, the age and sex of the convict and that the physical and moral integrity of the prisoners must be respected.

Since the foundation (1948), Brazil has been an integral part of the Organization of American States.[10]. This organization aims to make a contribution towards increasing peace, justice, democracy, the rule of law, human rights and assistance among countries belonging to the American continent. The Brazilian State is also a signatory to the American Declaration of Rights and of Men [11], from 1948. In article 25 provides for the prisoner's right to humane treatment as long as he is deprived of his liberty. The following article (26) enshrines the prohibition of cruel, infamous or unusual penalties.

It is also a signatory of the American Convention on Human Rights [12], from 1969. In its article $4 .^{\circ}$ determines that the death penalty can only be applied to the most serious crimes, if there are countries that have not yet abolished it. And in countries where the death penalty has been abolished, it cannot be restored. This penalty can never be applied for political crimes, nor can it be applied to those who, at the date of the crime, are under eighteen years of age, or over seventy, or are pregnant women. Those sentenced to death are entitled to request amnesty, pardon or commutation of the sentence and while the request is pending the sentence cannot be carried out. Article 5 prohibits torture, cruel, inhuman or degrading treatment and punishment. He adds that the main purpose of the sentences is to obtain improvement and the social rehabilitation of the convicts.

We also highlight the Inter-American Democratic Charter [13], from 2001. This charter predicts, in article $7 .^{\circ}$ a democracy as "a condition for the full and effective enjoyment of human rights and fundamental freedoms". Finally, the Americas Social Charter [14], from 2012, not having a position especially on penalties, it establishes, in article 1, the freedom, equality and dignity of all citizens and the need to respect human rights and fundamental freedoms as a way of strengthening democracy and social justice.

The brazilian Criminal Enforcement Law [15] $n^{\circ} 7.210$, from July 11, of 1984, predicts in article $1 .^{\circ}$ that the execution of penalties must materialize the provisions of the sentence and provide conditions for the "harmonious social integration of the condemned and the inmate". In Article 25, paragraph I, prescribes guidance and support for the later reintegration of the convict. This law contains a chapter on work, which begins in article 28 , where the work of the convict is seen as a "social duty and condition of human dignity", for educational and productive purposes. It establishes, in article 31, the obligation to work for the person sentenced to a deprivation of liberty, according to his aptitudes and capacities. Mandatory work makes an exception for those convicted of a political crime (Article 200). According to article 32, the work to be assigned to the convict must take into account his / her qualifications, personal condition, the future needs of the prisoner and the market opportunities. Under the terms of article 39, the performance of work is one of the convicted person's duties, with respect for their physical and moral integrity and proportionality in the distribution of time for work, rest and recreation (articles 40 and 41). Prison establishments must have work areas (Article 83). Convicted persons over 70 years of age, critically ill people, women convicted with minor or physically or mentally disabled children and pregnant women (Articles 114 and 117) may be released from work. Article 126 provides for the possibility of discounting part of the sentence for the execution of work or study, with prisoners seeing this solution as a way of shortening the sentence.

\subsection{The question of resocialization}

The answers to question 7 showed that the majority of students are in favour of the correction / resocialization of the prisoner imposed by the State, that is, even against the sentenced person's will, with 8 favourable responses and 5 against. Having studied the Brazilian legal framework, we found that, after all, this result is compatible with the formulation of the law, despite the existence of the constitutional guarantees enshrined in Article 5, which must sustain human life, in its various dimensions and aspects. The dignity of the human person, as Casalta Nabais says, is a "fundamental value or principle that has, afterwards, very important concretizations in the entire Constitution (...)", 
pointing out this Author "the precedence of the constitution of the person over the constitution of society (economic) and the constitution of the State (political)" [16].

Everything resides in the identification of work as a strict right of the prisoner that he can exercise or not, or as his duty to himself and to society. We have seen that Brazilian law supports this second conception. We believe that the Brazilian legislative power adopts the way of work imposed on prisoners as an opportunity that provides them with a professional background capable of making them fit for the labour market, when they cease serving their sentences, in order to rebuild their lives and have a more prosperous future. But work as a duty of the prisoner takes us on a path close to the so-called forced labour, which, in turn, is prohibited by the Brazilian Constitution.

Sérgio Tamer draws attention to the need for professional training in prisons, but places the central point in its interconnection with "formal schooling", which should not be limited to the fact that the prisoner acquires only skills for the work environment. Moreover, this is the aspect adopted in the State Education Plan in the prisons of Maranhão [2]. Lemos, Mazilli and Klering [17] show the need for work not to be just a simple mechanical routine, merely reproducing tasks, but to be organized in such way that allows the prisoner's personal development, as can be seen in the final conclusions of his article. Resocialization does not depend only on job opportunities. Educations, teaching, psychological assistance, religious assistance, the frequency of programs aimed at transmitting ethical and civic values, among others, are factors of high importance in the process of regeneration of prisoners, which may influence them in a determinant way in your future life.

Almost all students are opposed to the death penalty and corporal punishment. As for life imprisonment and the penalty of forced labour, students are already more divided: 4 of them accept life imprisonment and 6 admit forced labour as a sanction. We tend to interpret this wide admissibility of the penalty of forced labour as a consequence that results from the mandatory work of the prisoner that is imposed by the Brazilian law of execution of the sentences, since the work of the convict is considered as "social duty" and not as "social right".

The Brazilian Constitution prohibits the penalty of forced labour. Within this legal framework, the preventive ends of the sentences defended by the students unanimously also become understandable. A possible reading of these results will be as follows: students believe in resocialization through the condemned person's work, admitting that with preparation and professional experience, prisoners, in the future, commit themselves to a career and may become autonomous, in order to return to social life responsibly and integrate into society without committing other crimes.

\section{CONCLUSIONS}

The Brazilian master students who answered the questionnaire revealed:

a) To be mostly against the application of life imprisonment, the death penalty, forced labour and corporal punishment, being generally aware of human rights as to the type of punishment and its way of execution;

b) To be unanimously in favour of the preventive purposes of sentences;

c) Mainly support the application of more severe penalties and the imposition of correction / resocialization of convicts, even against their will;

d) To consider Brazilian criminal justice between reasonable and very weak;

e) To feel insecure in their home country and to have already been victims of a crime;

f) After analysing the relevant legal diplomas, we saw that the Brazilian Constitution prohibits the death penalty, perpetual punishment, forced labour and cruel penalties and the Law on the Execution of Penalties imposes the obligation of work by the prisoner, with work being his duty in name of resocialization purposes. We interpret that it is because of this legal context that respondents accept resocialization as a right of the State and not as a right of the condemned.

\section{REFERENCES}

[1] R. Greco, Sistema prisional. Colapso atual e soluções alternativas, 2. ${ }^{a}$ ed. Niterói: Ed. Impetus, 2015.

[2] S. Tamer, "Derechos sociales en las cárceles. Una experiencia en un de los más peligrosos presídios del mundo", Ratio Legis, pp. 56 ss., 2019. 
[3] Brasil. Ministério da Justiça e Segurança Pública Departamento Penitenciário Nacional. Levantamento Nacional de Informações Penitenciárias Atualização - Junho de 2016, Brasília - DF 2017. Accessed 4 January, 2021. Retrieved from: https://www.conjur.com.br/dl/infopenlevantamento.pdf.

[4] N. Machado and I. Guimarães, "A Realidade do Sistema Prisional Brasileiro e o Princípio da Dignidade da Pessoa Humana", Revista Eletrónica de Iniciação Científica, Vol. 5, n. ${ }^{\circ}$ 1, pp. 566581, 2014. Accessed 4 January, 2021. Retrieved from: www.univali.br/ricc.

[5] L. Souza, "Análise jurídica do sistema penitenciário brasileiro à luz dos tratados internacionais em direitos humanos", Revista Direito em Ação, Vol. 14, n. ${ }^{\circ}$ 1, pp. 1-21, 2015.

[6] E. Zaffaroni, Derecho Penal. Parte General, 2. ${ }^{a}$ ed. Buenos Aires: Sociedad Anónima Editora, Comercial, Industrial y Financiera, 2002.

[7] C. Beccari, Dos Delitos e das Penas (J. Faria Costa, Trans.). Lisboa: Fundação Calouste Gulbenkian. 1998.

[8] F. Monteiro, "A aplicação das normas no âmbito jurídico-penal: reflexões epistemológicas" in Direitos de personalidade e sua tutela (M. C. Andrade Coord.), Vol. I, pp. 151-172. Lisboa: Rei dos Livros, 2013.

[9] Accessed 4 January, 2021. Retrieved from: https://www2.camara.leg.br/atividadelegislativa/legislacao/Constituicoes_Brasileiras/constituicao1988.html/arquivos/ConstituicaoTexto Atualizado_EC101.pdf.

[10] Known by the acronym OAS, which is based in Washington, United States of America.

[11] Accessed 4 January, 2021. Retrieved from: http://pfdc.pgr.mpf.mp.br/atuacao-e-conteudos-deapoio/legislacao/direitos-humanos/declar_dir_dev_homem.pdf.

[12] Accessed 4 January, 2021. Retrieved from: https://www.cidh.oas.org/basicos/portugues/c.convencao_americana.htm.

[13] Accessed 4 January, 2021. Retrieved from: https://www.oas.org/charter/docs_pt/resolucao_pt.htm.

[14] Social Charter of the Americas/Carta Social das Américas (2012). Accessed 4 January, 2021. Retrieved from: https://www.google.com/search?client=firefox-b$\mathrm{d} \& \mathrm{q}=$ Social+Charter+of+the+Americas.

[15] Accessed 4 January, 2021. Retrieved from: http://www.planalto.gov.br/ccivil_03/LEIS/L7210.htm.

[16] J. Nabais, "Autonomias e forma de Estado", in Estudos em Homenagem ao Prof. Doutor Manuel da Costa Andrade, Vol. III, pp. 339-359. Coimbra: Boletim da Faculdade de Direito, 2017.

[17] A. Lemos, C. Mazilli, L. Klering, "Análise do trabalho prisional: um estudo exploratório", Revista de Administração Contemporânea, Vol. 2, n. ${ }^{\circ}$ 3, 2012.

\section{Other documents Consulted}

[18] Constitution of the Federative Republic of Brazil / Constituição da República Federativa do Brasil (1988). Accessed 4 January, 2021. Retrieved from https://www2.camara.leg.br/atividadelegislativa/legislacao/Constituicoes_Brasileiras/constituicao1988.html/arquivos/ConstituicaoTexto Atualizado_EC101.pdf.

[19] American Declaration of the Human Rights and Duties of Men / Declaração Americana dos Direitos e Deveres do Homem (1948). Accessed 4 January, 2021. Retrieved from: http://pfdc.pgr.mpf.mp.br/atuacao-e-conteudos-de-apoio/legislacao/direitoshumanos/declar_dir_dev_homem.pdf.

[20] American Convention on Human Rights / Convenção Americana sobre Direitos Humanos (1969). Accessed 4 January, 2021. Retrieved from: https://www.cidh.oas.org/basicos/portugues/c.convencao_americana.htm.

[21] Inter-American Democratic Charter/ Carta Democrática Interamericana (2001). Accessed 4 January, 2021. Retrieved from: https://www.oas.org/charter/docs_pt/resolucao_pt.htm. 
[22] Penal Execution Law/ Lei de Execução Penal, No. 7.210, of 11 of July of 1984. Accessed 4 January, 2021. Retrieved from: http://www.planalto.gov.br/ccivil_03/LEIS/L7210.htm. 